\title{
Testis-Specific Histone H1
}

National Cancer Institute

\section{Source}

National Cancer Institute. Testis-Specific Histone H1. NCI Thesaurus. Code C162801.

Testis-specific $\mathrm{H} 1$ histone (255 aa, $28 \mathrm{kDa}$ ) is encoded by the human H1-7 gene. This protein is involved in the histone-protamine transition of sperm chromatin. 